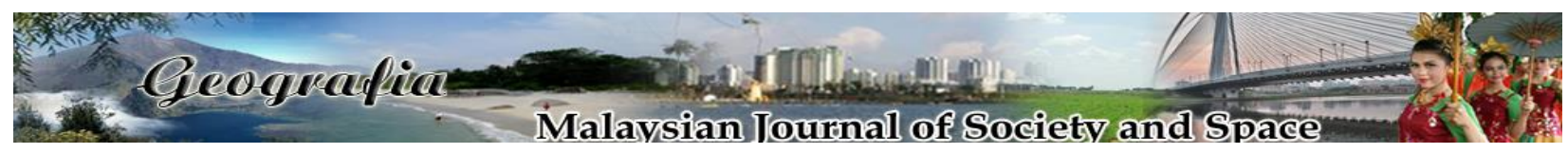

\title{
The changing nature and pattern of intra-party conflict in Nigeria's fourth republic: Critical assessment of All Progressives Congress
}

\author{
Muhammad Aminu Yahaya \\ Department of Public Administration, Faculty of Arts and Social Sciences, \\ Gombe State University, Nigeria \\ Correspondence: Muhammad Aminu Yahaya (email: abusafiyya9032@gmail.com)
}

Received: 13 January 2019; Accepted: 11 March 2019; Published: 14 May 2019

\begin{abstract}
This study is an analysis of the nature and pattern of intra-party conflict in Nigeria's Fourth Republic with specific reference to the ruling All Progressives Congress (APC). Intra-party conflict has been the norm in Nigerian politics leading to crises, setback and failure of many parties to forge ahead for proper democratisation in Nigeria including the ruling parties in many instances. The problem is the way in which intra-party conflict is becoming the bane of democratisation and good governance in Nigeria for many decades and despite the previous experiences, the phenomenon continued unabated. The study investigated the new dimension of intra-party conflict in Nigeria taking the APC as the case study. The study used a qualitative method of data collection and analysis. Primary and secondary sources of data were used. The primary data involved in-depth interviews with some selected informants from the relevant institutions and agencies related to the APC and the crises such as the national party executives, senior officials of the Independent National Electoral Commission (INEC) and academicians that are experts in the area of study. The secondary sources included were books, journals, newspapers, internets and other documented materials. The data obtained were discussed using content analysis where thematic analytical interpretations were used in the discussions. The research discovered that, the intra-party conflict under the APC has taken a new dimension where the members of the ruling party constituted an opposition and a stumbling block for the party's progress and governance. The work recommends that intra-party conflict of APC and other Nigerian political parties can be resolved through constitutional reforms, institutionalisation of party ideology and principles as well as strict sanctions from the national party leaders.
\end{abstract}

Keywords: All Progressives Congress, democracy, good governance, intra-party conflicts, Nigeria's fourth republic, political party 


\section{Introduction}

Intra-party conflict is a phenomenon that is currently trending in Nigerian democracy and Nigerian politics (Okhaide, 2012). The process of party primaries, candidate nomination and selection, party ideology and party principles are found to be faulty and undemocratic in nature (Jude \& Ika, 2013). The essence of internal democracy is to foster transparency, enhance democracy and sustain good governance in addition to a sound electoral conduct. All party members are expected to be given a fair treatment, equal opportunity and just platform for party representation if they indicate an interest towards that (Hallberg, 2008; Ojukwu \& Olaifa, 2011; Liebowitz \& Ibrahim, 2013).

In a context where internal party democracy is lacking, many problems emerged including the violation of the principles of party politics, undermining party ideology, anti-party activities and intra-party conflicts which jeopardise the chance of party in the electoral battle. Intra-party conflicts have been taking place in Nigerian politics since pre-independence period in various dimensions and all ramifications (Jude \& Ika, 2013; Toyin, 2014; Awofeso \& Irabor, 2016). However, the pattern and nature of intra-party conflicts in the Fourth Republic became more pronounced particularly among the members of the People's Democratic Party (PDP) which led the country for sixteen (16) years culminating into many serious crises such as decamping (Sule \& Yahaya, 2018) that led to the demise of the party as the ruling power in the 2015 General Election. The case with the current ruling All Progressives Congress (APC) is even consolidated and escalated in terms of the expansion and dimension of the crisis.

It is argued that intra-party conflicts and absence of internal democracy were some of the major factors that led to the loss of the PDP in the 2015 General Election (Adibe, 2015; Paden, 2015; The Centre for Public Policy Alternative, 2015) and the crises had offered an alternative and an opportunity for the then; opposition APC to surmount into power during the 2015 General Election. Unfortunately, the ruling APC in less than two years of its leadership found itself in a nature of intra-party conflicts that became worst and manifested in a dimension that has never been witnessed before in the history of intra-party conflicts in Nigerian politics.

This study critically examined the changing nature, new dimension and current pattern of intra-party conflicts in Nigeria which have never occurred before. The study also examined the implications of these crises on the future of Nigerian political parties, Nigerian democracy and politics in general.

This study has the overall objective of examining critically the causes, nature and implications of intra-party conflicts in the ruling APC in Nigeria. The other objectives of this study is to examine the new trend and dimension of intra-party conflicts in the ruling APC in Nigeria and to identify the future implications and policy implications of the crises and how it may affect the Nigerian democracy and politics.

\section{Literature review}

In this section, existing literature that are related to the subject matter of study were critically discussed to enable for the identification of the research gap and contribution to knowledge. The literature was thematically reviewed according to the following concepts: internal democracy, political parties, intra-party conflicts and the APC. 


\section{Internal democracy}

Internal democracy is the principles of putting on all party members on board for collective decision-making and politicking (Scarrow, 2005). Internal democracy is the pillar behind the sustenance of democracy in modern times and it fosters political development (Duverger, 1963; Sartori, 1977). Internal democracy should be all-inclusive and all-encompassing process of carrying all members together in the process of general party decision-making particularly in the election of the party executives, party primaries, representation, policy-making, fairness and transparency in the conduct of party affairs (Okhaide, 2012).

Internal democracy does not denote or is not interpreted as a total absence of conflict in the party or among the party members but, rather, it is a process of reaching a consensus on a laiddown principles and regulations based on harmony as accepted by members as rules in playing the game. Through a proper internal democracy, sound and credible acceptable candidates emerged in the process of party primaries which enable for fielding of competitive contestants at all levels. Discipline and collective responsibility would be maintained through the process of internal democracy. Any party that is bereft of internal democracy is heading towards failure and defeat in general elections and it may end up collapsing (Omilusi, 2016). Internal democracy includes parties' process of selection of candidates, consultation, internal party discipline and sanction, promotion of parties' ideology, accountability (Awofeso et al., 2017) There are two major methods of promoting internal democracy: the advocacy and legal/regulatory measures (Hallberg, 2008).

\section{Nigerian political parties}

Political parties are the engine room and the pillar of democratic rule which provide a platform for electioneering process and other political activities. Political parties are conceived as the conglomeration of men who share the same ideology, principles and political views who strive to acquire power in order to promote their ideas at the governmental level (Johari, 2012:423). Many scholars (Lowell, 1913; Schumpeter, 1942; Michel, 1965; Duverger, 1966; Sartori, 1976) identified political parties as a group or collection of few people who designed policies and rules of conduct for the large crowd of people who have the same interest with them.

Other scholars (Appadorai, 2004; Kapur, 2009; Johari, 2011) also identified political parties as a group of ideologically assembled men with the same principles who sought to promote their interest at governmental level by involving themselves in political activities. Parties played important functions in democratic ruling such as representation, opposition, recruitment and training of leaders, harmonising different interests, providing alternative choice framework and social services to the society (Norris, 2005; Speijcken, 2011).

In Nigeria, there are numerous parties which existed before and after the political independence. Many of them flourished and later declined or ceased to exist totally while others remain in existence. Nigerian political parties in the First Republic (1960-1966), Second Republic (1979-1983), Aborted Third Republic (1991) and the Fourth Republic (1999-2018) share the same characteristics and have the same nature in their formation and outlook. They are mostly regional, ethnic, religious and elite-based in their feature (Agbaje, 2008).

Nigerian political parties started right from nationalist movement in the 1920 s and later transformed into decolonisation activities which made them a colonial heritage just like most African parties in the post-colonial era. The parties are not ideological, and they lack political 
principles of democratic governance and such has been the situation of Nigerian parties since independence in 1960 (Salih, 2003:57). The first parties that emanated in the First Republic: Action Group (AG) for Yoruba West, National Council for Nigeria and Cameroons (NCNC) mostly dominated by Igbo East and Northern People Congress (NPC) for Northern region represented ethnic and religious group than party ideology and this outlook set the foundation for continuous ethno-religious and regional parties in the Second Republic (1979-1983), Aborted Third Republic (1992) and the current Fourth Republic (1999-date) (Akinboyega \& Anifowose, 2008).

The parties that emerged in the Second Republic (NPN, GNPP, UPN, UPGA and NNP) looked similar to the ones in the First Republic in terms of structure and approach. The parties in the Aborted Third Republic seemed the continuation of the previous ones in disguise. It can be argued that the People Democratic Party (PDP) looked more national in orientation from 1999 to 2015 dominating five out of the six geo-political zones in Nigeria in the Northeast, Northwest, Northcentral, Southeast, Southsouth but the Southwest still maintain a regional and ethnic party of Alliance for Democracy (AD) which later transformed into Action Congress of Nigeria (ACN) that joined the coalition which established APC in 2013. The All Nigerian People Party (ANPP) also was dominantly presence in Northern Nigeria and despite the overwhelming domination of PDP it later turned out to be an opposition with strong presence only in the Southeast and Southsouth after its defeat in the 2015 General Election by APC. The APC like PDP, became a nationally dominant party in more than four out of the six geopolitical zones in the country.

\section{Intra-party conflict}

Nigerian political parties have a reputation of intra-party conflicts since political independence in 1960 but, that of the Fourth Republic has been more pronounced particularly the former ruling PDP but, most especially the present ruling APC in which the conflicts have taken a new changing dimension that has never been witnessed before in the history of Nigerian politics. These intra-party conflicts resulted in many undesirable political setbacks such as the politics of decamping, factions, anti-party activities, collapse of the parties and political violence (Jude \& Ika, 2013).

Besides the above, intra-party conflicts occur because of imposition of candidates, politics of godfatherism, absence of internal democracy, corruption, lack of ideology and selfishness. The conflicts can be managed through a mechanism of internal party democracy and promotion of party ideology and principles (Awofeso et al., 2017; Toyin, 2014). Some factors emerged such as lack of ideology, imposition of candidates, party funding, zoning formula in Nigerian context, party primaries and party executive arbitrariness. These are the main reasons for intra-party conflicts in Nigerian democracy leading to undemocratic practice (Ojukwu \& Olaifa, 2011).

Due to the above factors identified by various scholars, it could be established that the existence of PDP as the major ruling party which ruled from 1999-2015 has set the foundation for intra-party conflicts. The party became formidable and domineering in the country to the extent that it violated democratic principles and internal democracy, making many members aggrieved causing anti-party activities, decamping and other undemocratic practices. The violation of an informal party agreement for zoning of presidential seat between the North and the South for 8 years each was violated by President Jonathan in 2011 which further polarised the party beyond repair (Aleyomi, 2013). By the end of 2013, PDP was speedily scattered 
towards its political doom because of intra-party conflicts. The nature of the conflicts is all encompassing involving the national executive and the legislature, intra-state internal crisis between one faction and another and party executives.

The ruling APC proved to be worst in its internal schism because barely a year after its assumption into power in 2015, it enmeshed itself into a serious internal crisis involving the National Assembly members at both the Senate and the House of Representatives starting from the choice of the leadership of the two chambers in which the process was disenchanted by the executive and the party leadership. Within a short period of a time, the party constituted itself as an opposition of itself despite having the majority in the National Assembly, at state and local government levels. Another fresh edition of conflicts set in between the executive and the legislature which is prolonged and persisting presently has led to the decamping of more than one hundred senior party members into the opposition PDP and other opposition parties. This scenario made the case of APC's internal crises an entirely different; one has never witnessed in the history of world democracy where a ruling party with the majority constituted itself as its own opposition in government.

\section{The All Progressive Congress (APC)}

The APC was formed on 6 February 2013 as a strongest opposition in preparation for the 2015 General Election. The APC emerged out of the merger of three biggest opposition political parties and a faction of the fourth one to establish a stronger opposition that will challenge the ruling PDP which has ruled for straight sixteen years. The parties that formed APC merger are: Action Congress of Nigeria (ACN), All Nigeria Peoples Party (ANPP), a faction of All Progressive Grand Alliance (APGA) and Congress for Progressive Change (CPC). The merger was a result of a prolong attempt to wrestle power from PDP because the opposition parties realised that they can never defeat PDP individually since each of the opposition has its stronghold. For instance, ACN dominated the Southwest, ANPP and CPC dominated the Northeast and Northwest while APGA dominated some Southeastern states. The first attempt was made in 2011 between the ACN and CPC which failed to materialise in the late hours due to clash of personal interests by the party stalwarts.

The electoral body, the Independent National Electoral Commission (INEC) registered the APC after fulfilling all the criteria for registration of parties constitutionally. The major boost or strength that the newly established APC received was the emergence or decamping of strong PDP members called the newPDP which was a faction that emerged after disenchantment of some members of the PDP from the party's convention in 2014. The party welcomed the new PDP members involving five state Governors of Adamawa, Kano, Kwara, Rivers, and Sokoto, ten serving Senators in the upper chamber, 22 serving Members Federal House of Representatives including the Speaker of the House and other top PDP founding fathers such as Alhaji Atiku Abubakar (Sule et al., 2018).

\section{Theoretical framework}

The Elite theory emerged in the 1930s by the philosophical works of the Italian Sociologists Vilfredo Pareto, Gaetano Mosca and Political Scientists Roberto Mitchel and Jose Ortega. The main assumptions of this theory include among others that in every society there are two main 
divisions of classes, the elite and the masses. This division is asymmetrical and not coordinated because one of the classes is the leader with the other being the led. There are various attempts at explaining Elite propositions critically by scholars (Varma, 2005; Asirvatham \& Misra, 2011; Mahajan, 2011; Johari, 2011, Johari, 2012; Gauba, 2012).

Another assumption of Elite Theory is the minority few which belongs to the ruling class is influential in decision making, politically developed and economically better off. They possessed exceptional skills and are sublime for leadership owing to the extraordinary power they are endowed with and leadership traits which put them in a natural position and advantage for domination and control of the state comfortably. They manipulated their way into power and sustained it since they possessed skills and knowledge for leadership. The Theory posses that; the Elite can employ dubious means and dirty game of politics in the power control and in the control of the economy (Varma, 2005; Mahajan, 2011; Asirvatham \& Misra, 2011; Johari, 2012).

In applying this Theory within the context of this study, it is germane to note that the elite are the dominant members of political parties in Nigeria because majority of the poor do not even possess party membership registration talk less of being involved in the process of party decision. The elites in their struggle to acquire and control power at all cost denied other less privilege members of equity and equality in the process of decision-making in the party in terms of nomination, selection, party primaries and representation on the platform of the party and this has led to serious crises and disenchantment among the party members leading to intra-party conflicts and this is exactly the situation in Nigerian context and in the context of this study.

\section{Methods and study area}

The research employed a qualitative data approach which used both primary and secondary sources of data. In-depth interviews were used as the primary means in the data collection process in which some stakeholders that were related to the subject matter of study were interviewed. The primary data were obtained from the in-depth interviews conducted using four different identified groups categorised into four groups accordingly. Category A included six (6) politicians from different position of elective offices, category B is six (6) party stakeholders from the two major political parties in the country the APC and PDP, category C is the (4) senior officials of the electoral body the Independent National Electoral Commission (INEC) and category D is two (4) academicians who specialised in the area of study from two major universities in Nigeria. This makes a total of 20 informants/participants from the four categories as suggested by Bogdan and Biklen (2007) as well as Creswell (2014). On the other hand, the secondary data consisted of textbooks, journals, internet sources and data from newspapers. The data obtained from the in-depth interviews and secondary sources were combined and discussed using thematic analysis. These were then used for further interpretations and findings, in addition to the application of the theoretical framework applied in the study.

Nigeria is a country with multi-ethnic and multi-religious as well as multi-cultural entities which make the politics a war affair and in particular during elections where the voting pattern is always influenced by the above variables. From the culmination of major and minor ethnic groups during pre-colonial period, the British colonisers amalgamated the diverse multicultural entities into a single unit called Nigeria in 1914. It was a union of an imbalance entity with three major ethnic group namely Hausa/Fulani (North), Igbo (South) and Yoruba (West) dominating the minorities in the politics of the country since political independence (Africa Centre for 
Strategic Studies, 2015).

Nigeria is currently divided into six geo-political zones as North East, North West, North Central, South West, South East and South-South. The country is also divided into 36 states and the Federal Capital Territory in Abuja (FCTA). The country is the most populous African nation and the tenth most populated in the world with an estimated population of 200 million from the projection of the 2006 Population Census (Africa Centre for Strategic Studies, 2015:7). The North is believed to be the majority according to 2006 population census, in terms of population dominated by Hausa/Fulani Muslims while the South is dominated by Igbo Christians and mixed Yoruba Christians and Muslims. This explains why the North is always a decisive force in the electoral politics of the country.

\section{Results and discussion}

In this section, the data obtained from the field and the existing literature in addition to the theoretical framework adopted were presented, discussed, analysed and interpreted using themes as explained earlier in the methodology.

It is clear that the foundation for the ruling APC's crises started right from its inception onto power after the 2015 General Election when it won the election with a landslide victory at all levels especially the Federal and State governments. It set the record of defeating the incumbent ruling PDP which was unprecedented in the history of the country and the defeat was adjudged to have been in a fair and credible election. However, the seeds of discord were sown right from the formation of the APC in 2013 when the party welcomed all the disgruntled elements from the then, ruling PDP and other opposition whose main interest was not national development or democratic consolidation but self-serving interest of power thirsty and power control. The major features of the crises were summarised below based on the findings of the work.

\section{The national assembly leadership crises}

The National Assembly has the majority APC members in the two chambers, the Senate and the House of Representatives and it has the majority Governors' seat and a government at the centre controlling about 22 states in the Federation. The formation of the leadership of the National Assembly was the watershed for internal conflicts that affected the APC from the commencement of its ruling. The national party executive and the executive arm of government preferred Senator Lawan Ahmad from Yobe State to lead the Senate as the President while Honourable Femi Gbajabimiala from Lagos State to be the Speaker House of Representatives. Some members of the National Assembly kicked against this arrangement and used their opportunity and turned against the preference of the party and the executive arm of government. They elected Senator Bukola Saraki from Kwara State to be the Senate President and Honourable Yakubu Dogara from Bauchi State to be the Speaker of the House. Many members that are loyal to the party and the executive were aggrieved (Nwajiuba, 2015).

The second crisis that emerged among the lawmakers in the APC was the trial of the Senate President for false declaration of assets when he was the state Governor by the Code of Conduct Tribunal. He was taken to the CCT for trial and the Senate was fragmented into two, the proSaraki vowed to frustrate the trial at all cost while the anti-Saraki decided that he must be impeached and face the full wrath of the law. The pro-Saraki accused the executive arm of 
government and the party executive of plotting the trial to oust Saraki from the Senate President Seat. (Ogundipe, 2016).

The third dimension of the crisis is the whistle blowing incidence in which a member from the ruling APC in the Federal House of Representatives Abdulmumini Jibrin from Kano State revealed that there was budget padding in the House in the 2016 budget presented by the executive. The member was suspended because of such revelation and all efforts by the executive and party officials to restore him and resolve the conflict failed. He stayed suspended until March 2018 when he was called back. The Senate also witnessed such incidence in which Senator Ali Ndume from Borno State was suspended in March 2017 for six-month because of his call for the investigation of the issue of certificate forgery by one of the Senators Dino Melaye (Sahara Reporters, 2017).

The crises in the APC were not surprising at all because if one looked at the nature and the antecedents that heralded the formation of the party, it is clear that such issues are impending. However, they have manifested earlier, and they have been pronounced more than expected. The party is heading towards its doom just the PDP way if care is not taken. This is seriously affecting our democracy and performance of government at all levels. The party lacks ideology and principles as it is taken over by the opportunities and politicians with unresolved grievances from the former ruling PDP.

Similarly, the Elite theory is practically applicable here because it is expressing that the ruling elites or politicians are selfish and greedy, and they felt that they have the natural right to rule at all cost which made them to fight each other in the process of allocation and distribution of offices. This is manifested in the way the APC members in the National Assembly forged themselves into the leadership affairs of the teo chambers as against the will of the party executive.

\section{The ruling APC as opposition onto itself}

Surprisingly and ironically, the ruling APC came up or found itself in a kind of intra-party conflict that have never been witnessed in the history of the country, Africa and indeed, world politics at large. It constitutes itself as an opposition of itself at both the National Assembly and at State levels. For instance, the National Assembly members became a stumbling block for passage of bills, budgets, appointments and other public appropriations presented to it by the executive arm of government at the national level. It had turned down the appointment of the Chairman of the Economic and Financial Crimes Commission (EFCC) Magu three times despite the insistence by the Presidency that he must be approved. Similarly, they had been in logger head with the boss of the Nigerian Custom Services (NCS) on trivial issues calling him severally into the house to embarrass him because he is loyal to the executive. They had also turned down the appointment of ambassadors presented to them by the President while at the same time delaying the passage of the 2016, 2017 and 2018 budget for almost an average of seven months each to frustrate the performance of the government. One of the informants consulted in the work revealed in his own words that:

“...The ruling APC set the record of being its own internal opposition even without a challenge from the opposition parties. The National Assembly members elected on the platform of the party constituted themselves into an opposition of the executive always attempting to frustrate the government in terms of speedy passage 
of bills, budget and appointment. This has really affected the assessment and performance of the government and it has not being witnessed before in Nigerian political history".

In the theoretical perspective, the Elite Theory can clearly and practically explain this phenomenon in the sense that it is a case of the elite struggling for power and power control for economic benefit that is making them to ignore the masses and national interest thereby enmeshing themselves in internal crises irrespective of the consequences provided their selfdesires would be attained at all cost.

\section{State APC internal crises}

The ruling APC despite being the majority ruling in 22 states out of the 36 in Nigeria, is currently having one crisis or the other in most of the states that its ruling internally among the party members that are holding either elective or appointive political positions., the crises are summarised below in the table for easy clarification.

Table 1. The state APC internal crises and their manifestations

\begin{tabular}{lll}
\hline State & \multicolumn{1}{c}{ Nature of crises } & \multicolumn{1}{c}{ Actors involved } \\
\hline Gombe & Party executive leadership faction & Senator Goje and Senator Bayero \\
Bauchi & Accusation of misutilisation of bailout funds & Governor and Federal lawmakers \\
Borno & Governorship succession tussle & Governor Shettima and Senator Kyari \\
Ondo & Governorship party primaries tussle & Governor Akeredolu and Bola Tinubu \\
Ogun & Governorship succession tussle & Governor Ajimobi and Senator Adeola \\
Kogi & Governorship ambition struggles & Governor Bello and Senator Dino Melaye \\
Plateau & Governorship ambition tussle & Governor Lalong and Minister Dalung \\
Niger & Personal clashes among politicians & Governor Bello and Federal lawmakers \\
Kaduna & Clash of interest among politicians & Governor El Rufa'I and Federal lawmakers \\
Kano & Power tussle & Governor Ganduje and Senator Kwankwaso \\
Imo & Party primaries disagreement & Governor Rochas and party executives \\
Benue & Power struggles & Governor Ortom and Senator Akume \\
Lagos & Party primaries & Governor Ambode and Bola Tinubu \\
Adamawa & Party primaries & Governor Bindow and Senators \\
\hline Sombering
\end{tabular}

Sources: Owete, 2017.

In addition to the above sources, one of the informants in the category of party executive officials narrated that:

"...It is surprising that barely two years into the ruling of APC, all the states are in fire of crises for one reason or the other all accruing from selfish desire and personal interest. Today, almost all the states governed by the APC are in disarray because of intra-party conflict".

In addition, the above statement is a clear and self-explanatory argument for the Elite theory used in the research work. It can be inferred from the above that the elites in their quest and struggles for power can engage in dubious acts that are even inimical to the survival of their parties which are the platform that they are using to secure power. 


\section{The politics of decamping}

The internal APC crisis has led to mass exodus of members into opposition PDP and other opposition parties unprecedented in the history of Nigerian politics. These events were summarised below in a tabular form.

Table 2. Summary of the incidences of APC decamping into opposition parties

\begin{tabular}{lc}
\hline Rank & Frequency \\
\hline Senators & 16 \\
House of representatives & 33 \\
Ministers & 1 \\
Top ranking politicians & 10 \\
\hline
\end{tabular}

In an in-depth interview, an informant stressed that:

"...It is surprising the way mass exodus hit the ruling APC at all cost and it is not only surprising but, shocking the way the party is losing top echelon politicians carelessly without doing anything about it. This may affect its chances of winning the 2019 General Election and performances as well because the party allowed the intra-party conflicts to prevail over the national interest and the party principles".

Similarly, the Elite theory can clearly explain this scenario because it seems the elite do not care about the masses or the national interest but, rather, their own personal ambition is their main concern only.

\section{Conclusion}

The study realised that intra-party conflicts emerged formidably in the ruling APC as manifested in all levels of government under the current APC-led government and it has fragmented the party beyond repair. Even though, the opposition parties are weak for now, there are possibilities that the crisis in the APC will strengthen them since the APC was once weak before but it was strengthened by the internal crisis of the PDP to secure power. The paper also concludes that, unless and until the crisis iscontained properly before the 2019 General Election, the party will perform poorly in the election and will collapse in the near future and this will jeopardise the nascent Nigerian democratisation and Africa at large. The paper observed that such crises exist as a result of the absence of ideology, principles, mechanisms of internal democracy and collective decision as well as the historical background of the emergence of APC as a party.

As a result of this conclusion, the paper recommends that the party should discipline or sanction those who are disobeying party principles and must go back to the drawing board to establish some rules governing intra-party relationship and members conduct ahead of 2019 General Election. In addition, APC needs to call for a genuine national convention to draw an ideology and principles of operation that all members must signed and agree on, so that those who are creating confusion in the party should be suspended from contesting in any political office against 2019 election in order to ameliorate the crisis. More so, collective decision and transparent party activities should be promoted effectively and the committee set up for 
reconciliation should endeavour to identify the root causes of the crisis, and make a feasible recommendation for implementation in order address the issue.

\section{References}

Adibe, J. (2015). The 2015 Presidential Election in Nigeria: The issues and challenges. Washington, Brookings Institution.

Agbaje, A. (2008). Political parties and pressure groups. In Anifowose, R., \& Enemuo, F. (Eds.). Elements of politics. Lagos, Sam Iroanusi Publishers.

Africa Centre for Strategic Studies (2015) After the Election, Fundamental Security Challenges Nigeria must Face. Washington DC. Retrieved from www.css.ethz.ch/en/services/csspartners/partner.html/087210

Akinboyega, S.O., \& Anifowose, R. (2008). Nigerian government and politics. In Anifowose, R., \& Enemuo, F. (Eds), Elements of politics. Lagos, Sam Iroanusi Publishers.

Aleyomi, M.B. (2013). Intra-party conflicts in Nigeria: The case study of Peoples Democratic Party. Journal of Sustainable Development in Africa, 15(4), 281-296.

Appadorai, A. (2004). The substances of politics. New Delhi, Oxford University Press.

Asirvatham, E., \& Misra, K.K. (2011). Political theory. New Delhi, S. Chand.

Awofeso, A., \& Irabor, P.A. (2016). Party Cross-Carpeting in Nigeria's Fourth Republic: Cases and causes. Journal of Public Administration and Governance Macrothink Institute, 6(3), $31-41$.

Bogdan, R.C., \& Biklen, S.K. (2007). Qualitative research for education: An introduction to theories and methods. Boston, Pearson Education.

Creswell, J.W. (2014). Research design: Qualitative, quantitative \& mixed methods approaches. California, Sage Publication.

Duverger, M. (1963). Political parties, their organisation and activity in modern state. New York, John Wiley \& Sons.

Duverger, M. (1966). Party politics and pressure groups: A comparative introduction. New York, Thomas Y. Crowell.

Gauba, O.P. (2011). An introduction to political theory. New Delhi, Vikrant Publishers.

Hallberg, T.M. (2008). Methods of promoting internal democracy in political parties. Retrieved from https://ngvotes.com.

Johari, J.C. (2011). Comparative politics. New Delhi, Sterling Publishers.

Johari, J.C. (2012). Contemporary political theory. New Delhi, Sterling Publishers.

Jude, M.A., \& Ika, M.G. (2013). The implications of intra-party conflicts on Nigeria's democratization. Global Journal of Human Social Science \& Political Science, 13(6), 1-13.

Kapur, A.C. (2009). Principles of political science. New Delhi, S. Chand.

Liebowitz, J., \& Ibrahim, J. (2013). A capacity assessment of Nigerian Political Parties: Democratic Governance for Development (DGD) Programme, UNDP, Nigeria. United Nations Development Programme.

Lowell, L.A. (1913). Public opinion and popular government. New York, Longman.

Mahajan, V.D. (2011). Political theory. New Delhi, S. Chand Publishers.

Michel, R. (1965). First lectures in political sociology. New York, Harper \& Row.

Norris, P. (2005). Political parties and democracy in theoretical and practical perspective. Washington, National Democratic Institute for International Affairs. 
Nwajiuba, C. (2015). APC and the National Assembly Crises. Retrieved from http://www.vanguardngr.com.

Ogundipe, S. (2017). Why Nigeria's ruling APC is in crisis-chairman Odigie-Oyegun. Retrieved from http://www.premiumtimesng.com.

Ojukwu, C.C., \& Olaifa, T. (2011). Challenges of internal democracy in Nigeria's political parties: The bane of intra-party conflicts in the Peoples Democratic Party. Global Journal of Human Social Sciences, 11(3), 25-34.

Okhaide, I.P. (2012). Quest for Internal Party Democracy in Nigeria: Amendment of electoral 2010 as an Albatross. International Journal of Peace and Development Studies, 3(3), 57-75.

Omilusi, M. (2016). An assessment of political parties and democratic consolidation in Nigeria's Fourth Republic. European Journal of Research in Social Science, 4(1), 34-50.

Owete, F. (2017). Analysis: 10 states where Nigeria's ruling APC is fighting itself. Retrieved from http://www.premiumtimesng.com.

Paden, J. (2015). Midterm challenges in Nigeria: Elections, parties and regional conflicts. United States Institute of Peace. Security analysis and research. Evolving Security Situation in Advance of Presidential Elections, 14 February.

Ejike, O. (2017). Party politics and divisive internal conflicts. Sahara Reporters Online. Retrieved from www.saharareportersonline.com.

Salih, M.J. (2003). African political parties. USA, Pluto Press.

Sartori, G. (1977). Parties and party system: A framework for analysis. Cambridge, Cambridge University Press.

Scarrow, S. (2005). Political parties and democracy in theoretical and practical perspectives: Implementing intra-party democracy. Washington, National Democratic Institute.

Schumpeter, J. (1942). Capitalism, socialism and democracy. New York, Harper \& Row.

Speijcken, R. (2011). Strengthening the role of political parties in public accountability. Netherlands, International Institute for Democracy and Electoral Assistance.

Sule, B., Azizuddin, M., Sani, M., \& Mat, B. (2018). Godfatherism and political party financing in Nigeria: Analysing the 2015 General Election. Geografia: Malaysian Journal of Society and Space, 14(1), 1-14.

Sule, B., \& Yahaya, M.A. (2018). The politics of decamping and the future of democracy in Nigeria. Conference Proceedings. Universiti Malaysia Kelantan.

The Centre for Public Policy Alternative (CPPA) (2015) Presidential election outcome. Retrieved from htttp://cpparesearch.org/nu-en-pl/nigeriadecides2015-analysis-implications/.

Toyin, O.S. (2014). Party conflicts and democratic consolidation in Nigeria (1999-2007). International Journal of Humanities and Social Sciences, 4(11), 248-269.

Varma, S.P. (2005). Modern political theory. New Delhi, Vrinda Publishers. 